\title{
Morphometric Analysis of Granulomas Induced by Mycobacterium bovis Suggests an Influence of IFN-Gamma on the Generation and Modulation upon Granulomatous Inflammatory Response in the Different Tissues
}

\author{
El Análisis Morfométrico de Granulomas Inducidos por Mycobacterium bovis \\ Sugiere la Influencia del IFN-Gamma en la Generación y Modulación \\ de la Respuesta Inflamatoria Granulomatosa en Diferentes Tejidos \\ *,**Tonya Azevedo Duarte; *Aryon de Almeida Barbosa Jr. \& *,***Sergio Arruda
}

DUARTE, A. T.; BARBOSA JR., A. A. \& ARRUDA, S. A morphometric analysis of granulomas induced by Mycobacterium bovis suggests an influence of IFN-Gamma on the generation and modulation upon granulomatous inflammatory response in the different tissues. Int. J. Morphol., 23(4):317-322, 2005.

SUMMARY: There is evidence in both human and experimental infection caused by Mycobacterium tuberculosis, that immunologic factors influence susceptibility to infection and the progress of the disease. The present study aims to evaluate the role of IFN- $\gamma$ upon inflammatory granulomatous response against M. bovis. To pursue that, C57BL/6 mice lacking the genes for synthesis of IFN- $\gamma\left(\right.$ IFN- $\left.\gamma^{\prime}\right)$ and their wild-type counterparts (IFN- $\gamma^{+/+}$) were intravenously inoculated with $M$. bovis. The ability of $M$. bovis to survive and replicate in the liver and lungs was evaluated by counting colony-forming unit (CFU). The histopathological features of granulomatous inflammatory response in the liver and lungs were analyzed during the infection by $M$. bovis. Granuloma parameters such as, size (sectional area), granuloma volume, volume density, and numerical density were calculated in each point of infection. Bacillary load was higher in both organs of the animals that were IFN- $\gamma^{/-}$than in IFN- $\gamma^{+/+}$mice. Granulomas were observed in the IFN- $\gamma^{/-}$mice after 30 days of infection and were detected earlier in controls (15 days of infection). Hepatic granulomas persisted in the IFN- $\gamma^{\prime-}$ mice, but in the IFN- $\gamma^{+/+}$mice control of the inflammation. In conclusion, IFN- $\gamma$ influenced the multiplication of $M$. bovis, as well as modulated the granulomatous inflammation.

KEY WORDS: Morphometry; Mycobacterium; Tuberculosis; IFN-g; Granuloma.

\section{INTRODUCTION}

Mycobacterial infections, particularly tuberculosis (TB), have become a leading global health threat (Bloom \& Murray, 1992; Cooper \& Flynn, 1995). WHO considers tuberculosis as global emergency. Incomplete understanding of the nature of protective inflammatory responses and contributing soluble molecules has hampered the development of effective vaccines and therapies (Wakeham et al., 1998).

Immunity to mycobacterial infection involves the induction of a cell-mediated immune response, whereby IFN$\gamma$-producing $\mathrm{T}$ cells activate the anti-bacterial defense mechanisms of infected macrophages to destroy, or at least contain, mycobacterial growth (Cooper et al., 1993; Orme
\& Cooper, 1999). IFN- $\gamma$, produced primarily by T cells and NK cells, plays a role in anti-mycobacterial immune responses by activating macrophages (Wakeham et al.).

Inflammatory response, induced by chronic presence of the mycobacterium in the tissue, is characterized by granuloma, a distinctive pattern of chronic inflammatory reaction (Robbins, 1999). Granulomatous formations, that surround infected cells and caseous necrosis, are an evidence of cellular response against mycobacteria infection. The granulomas formation and modulation are determinant for disease progression, i.e. latency or active disease. Thus, granuloma size and structure may play a role to the outcome of infection (Dannenberg \& Rook, 1994).

*entro de Pesquisa Gonçalo Moniz / FIOCRUZ, Salvador - Bahia, Brazil.

** Instituto de Ciências da Saúde, UFBA Salvador - Bahia, Brazil.

**** Escola Bahiana de Medicina e Saúde Pública. 
Granulomas are multi-cellular formations, where predominate macrophages, multinucleated giant cells, lymphocytes and necrosis. These macrophages respond to bacterial infections by the process of phagocytosis: the engulfment of bacteria (Gammack et al., 2004). Activated macrophages become efficient at phagocytosis and bacterial killing due to the presence of T cells and cytokines (Flesch \& Kaufmann, 1990). Phagocytes are attracted to sites of infection via the release of chemokines and cytokines (e.g. IFN- $\gamma$ ) by a variety of cell types. Infected macrophages release various chemokines (e.g. IL-8, MIP-2, IP-10, and MCP-1) that attract macrophages, neutrophils and T cells to sites of infection (Orme \& Cooper; Janeway et al., 1994). Additionally, macrophages produce cytokines (e.g. IL-12, TNF-a) that both up- and down-regulate adaptive immunity (Flesch \& Kaufmann; Flynn \& Chan, 2001).

Diverse studies using mice with targeted knockout of cytokines genes have yielded both predicted and unexpected findings with regard to the roles of cytokines in immune and inflammatory responses. In the present study, we extend the analysis, evaluating the role of IFN- $\gamma$ in the formation and modulation of the granulomatous process in IFN- $\gamma$ knockout mice and its respective wild type, which were infected with $M$. bovis. At the 15, 30, 50 and 100 days after infection were evaluated the kinetic of the infection in relation to the growth of the mycobacterium in the liver and the lungs of the mice, as well as the histopathological alterations that occurred in the two tissues.

\section{MATERIAL AND METHOD}

Animals and experimental infection. Mice - Female C57BL/6 mice deficient in IFN- $\gamma\left(\right.$ IFN- $\left.\gamma^{\prime-}\right)$ were obtained from School of Medicine, Ribeirão Preto, of São Paulo, Brazil. These animals and C57BL/6 wild-type mice (IFN$\gamma^{+/+}$) were maintained in isolator cages under specific pathogen-free conditions and provided with autoclaved food and water ad libitum.

Infection - Strain of M. bovis, obtained from INCQS (FIOCRUZ / RJ), was grown in Middlebrook 7H9 medium (Difco, Detroit, MI) supplemented with Middlebrook ADC to mid-log phase.

Mice were infected intravenously with an inoculum of $2 \times 105$ bacilli suspended in $50 \mathrm{ml}$ saline solution. At 15 , 30, 50 and 100 days post infection, animals were sacrificed and their liver and lungs were removed for enumeration of colonies forming units (CFU) of M. bovis, histopathological examination and morphological analysis.
Quantification bacillary load. The kinetics of bacterial growth was examined by plating serial dilutions of whole homogenates on nutrient Middlebrook 7H10 agar (GIBCO Becton Dickinson, Maryland, USA) and counts of colony forming units (CFU) were performed after 30 days of incubation, at $37^{\circ} \mathrm{C}$, under aerobic conditions.

Histopathology and Morphometry. Histopathology hepatic and pulmonary tissues of each animal were fixed in buffered-formalin, set in paraffin blocks and sectioned in $5 \mu \mathrm{m}$ slides. The sections were stained with haematoxylineosin (HE). The granulomas were characterized histopathologically by analyzing the HE stained slides and defined as a collection of more than ten mononuclear cells, as described previously by Cree et al. (1988).

Morphometry - histological sections of liver and lungs from the both groups of animals were examined by semiautomatic morphometry using the Leica Q500MC Image Processing and Analysis System (Leica Cambridge, Cambridge, England). The pathologist that did not know the slides examined all sections until microscopy and morphometric analysis had been completed. For morphometric measurements, a total sectional area of $13,41 \times 10^{5} \mu \mathrm{m}^{2}$ to each animal was evaluated. A spherical shape and normal size distribution were assumed. The following granuloma parameters were calculated: numerical density, size (sectional area) and volume density. Numerical density indicates the number of granulomas per unit of tissue considered. The surface area of the granulomas in the histological sections represented size. Volume density refers to the total volume occupied by the granulomas in the compartment of the hepatic and pulmonary tissue examined. To calculate the numerical density was assessed by to apply the Weibel's formula (1969).

Statistical analysis. Mean and standard error (SEM) of mean were calculated using a computer statistical package (Graph Pad Software, Version 3.00). Comparison of mean values between groups was done by an unpaired Student t-test. Values of $\mathrm{p}<0.05$ were considered statistically significant.

\section{RESULTS}

Quantitation of bacillary load in hepatic and pulmonary tissues by enumeration assay. In order to quantitative the mycobacterial burden in the liver and lungs after infection with $M$. bovis, we used a enumeration assay to quantification of colony forming units (CFU). We chose to focus on days $15,30,50$, and 100 of infection. The number of colonies in the organs was expressed per gram of weight of hepatic and pulmonary tissues (Table I). 
A morphometric analysis of granulomas induced by Mycobacterium bovis suggests an influence of IFN-Gamma on the generation and modulation upon granulomatous inflammatory response in the different tissues. Int. J. Morphol., 23(4):317-322, 2005.

Table I. Comparison of bacillary load in hepatic and pulmonary tissues of lungs of IFN- $\gamma^{\prime-}$ than IFN $-\gamma^{+/+}$mice

\begin{tabular}{cccc}
\hline \multicolumn{2}{c}{ Hepatic tissue } & \multicolumn{2}{c}{ Pulmonary tissue } \\
IFN- $\gamma^{\prime-}$ & $\begin{array}{c}\text { IFN- } \gamma^{+/} \\
\text {Mean } \pm \text { SEM }\end{array}$ & $\begin{array}{c}\text { IFN- } \gamma^{\prime-} \\
\text { Mean } \pm \text { SEM }\end{array}$ & $\begin{array}{c}\text { IFN- } \gamma^{+/+} \\
\text {Mean } \pm \text { SEM }\end{array}$ \\
\hline $60.3 \pm 6.4$ & $10.9 \pm 5.4^{*}$ & $3.0 \pm 0.4$ & $2.0 \pm 0.4$ \\
$67.8 \pm 6.2^{*}$ & $1.8 \pm 0.4^{*}$ & $7.5 \pm 0.2^{*}$ & $2.5 \pm 0.6^{*}$ \\
$71.5 \pm 15.2^{*}$ & $3.3 \pm 0.3^{*}$ & $48.1 \pm 7.9^{*}$ & $13.3 \pm 2.2^{*}$ \\
$93.9 \pm 4.0^{*}$ & $4.3 \pm 1.1^{*}$ & $49.9 \pm 3.0^{*}$ & $9.4 \pm 1.1^{*}$ \\
\hline
\end{tabular}

$* \mathrm{p}<0.05$ - $\left(\mathrm{IFN}-\gamma^{\prime-}\right.$ compared to IFN $\left.-\gamma^{+/+}\right)$

IFN- $\gamma^{/-}$mice - Mycobacterial infection was higher in both organs of IFN- $\gamma$ knockout mice. Bacillary burden increased in the liver and lungs of IFN $\gamma$ mutant mice during the study period. Apparently, in the IFN- $\gamma^{/}$mice there was no control of mycobacterial dissemination infection, which grew progressively. From day 30 to day 50-post infection, in the liver these mice, bacterial numbers increased significantly in IFN- $\gamma^{/-}$mice compared to IFN- $\gamma^{+/+}$mice, suggesting an uncontrolled growth to M. bovis in the liver and lungs of IFN$\gamma$-deficient mice.
IFN- $\gamma^{+/+}$mice - C57BL/6 wild type animals had a lower number of bacteria in their liver tissue during the period of infection compared to the mutant mice, indicating that they were better able to control mycobacterial growth than IFN- $\gamma^{\prime}$. Likewise, after 30 days of infection, the bacillary load in the liver stabilized without being completely eradicated. In contrast to the findings in the liver, there was a slight increase in bacillary load in the lungs during the initial infection period, which remained constant thereafter in the C57BL/6 wild type animals.
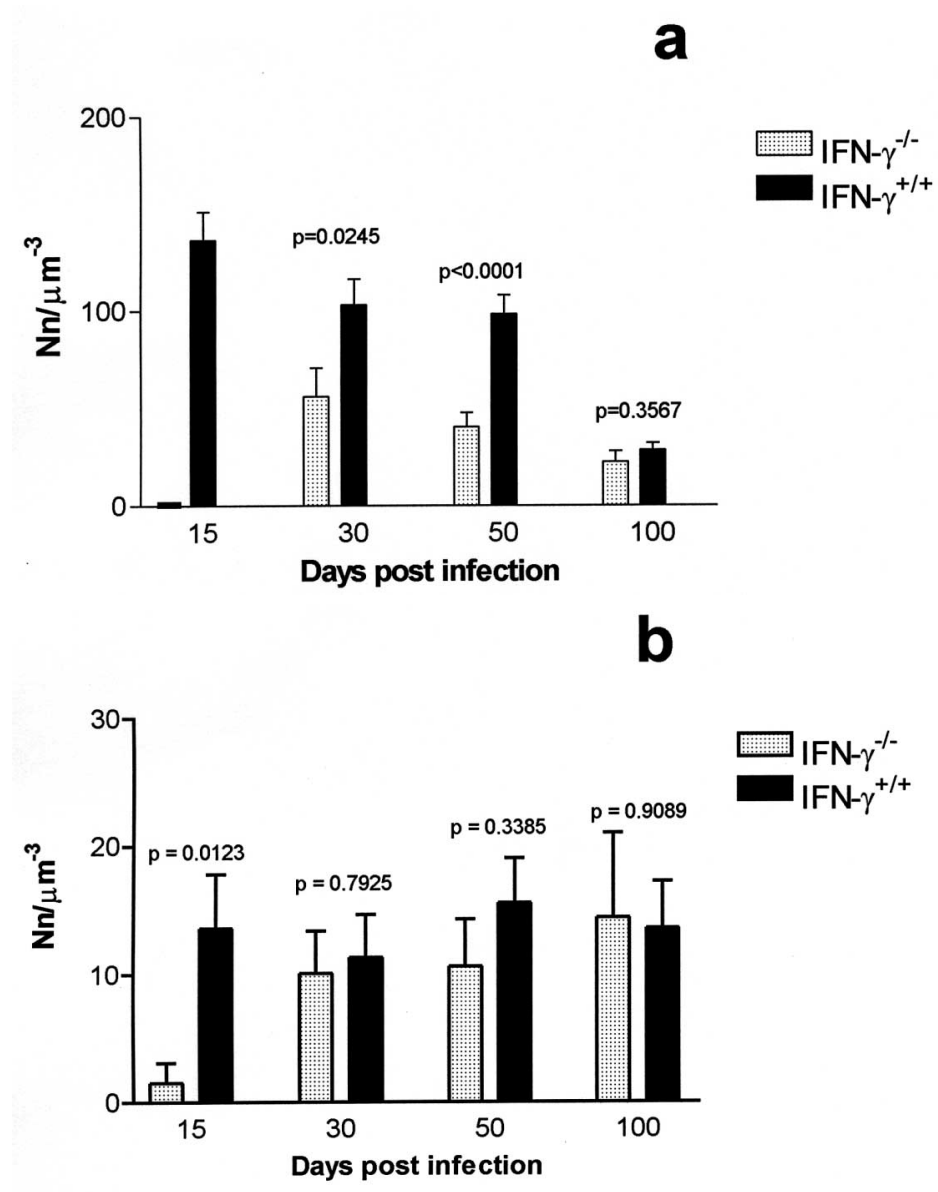

Fig. 1. Numerical density (Nn) of hepatic (a) and pulmonary (b) granulomas.
Histopathology and morphometry. Histopathological examination revealed striking differences between IFN- $\gamma^{-}$and IFN- $\gamma^{+/+}$mice. The histopathological analysis of the hepatic and pulmonary tissues included cellular characterization and quantification by morphometric analysis of the granulomatous lesions in both tissues.

IFN- $\gamma^{\prime-}$ mice - At 15 days after $M$. bovis infection, no granulomatous inflammatory lesions were observed in the liver of the IFN- $\gamma$ deficient mice (Figs. 1a, 2a and 3a), while a few granulomas were seen in the lungs of these animals (Fig.1b). These granulomas were composed by neutrophils, eosinophils and mononuclear cells (data not show). The formation of granulomatous lesions in the liver of IFN- $\gamma^{\prime-}$ mice infected with M. bovis appeared delayed and they are only detected at 30 days post infection and significant differences occurred, where the IFN- $\gamma$ deficient mice showed a lower number of granulomas per volume of evaluated hepatic tissue.

Between 30 and 50 days of infection, granulomatous lesions in liver are composed of few macrophages, neutrophils and eosinophils. No multinucleate cells or Langerhans cells were seen. These granulomas were evenly distributed throughout the liver, some of then were seen in 

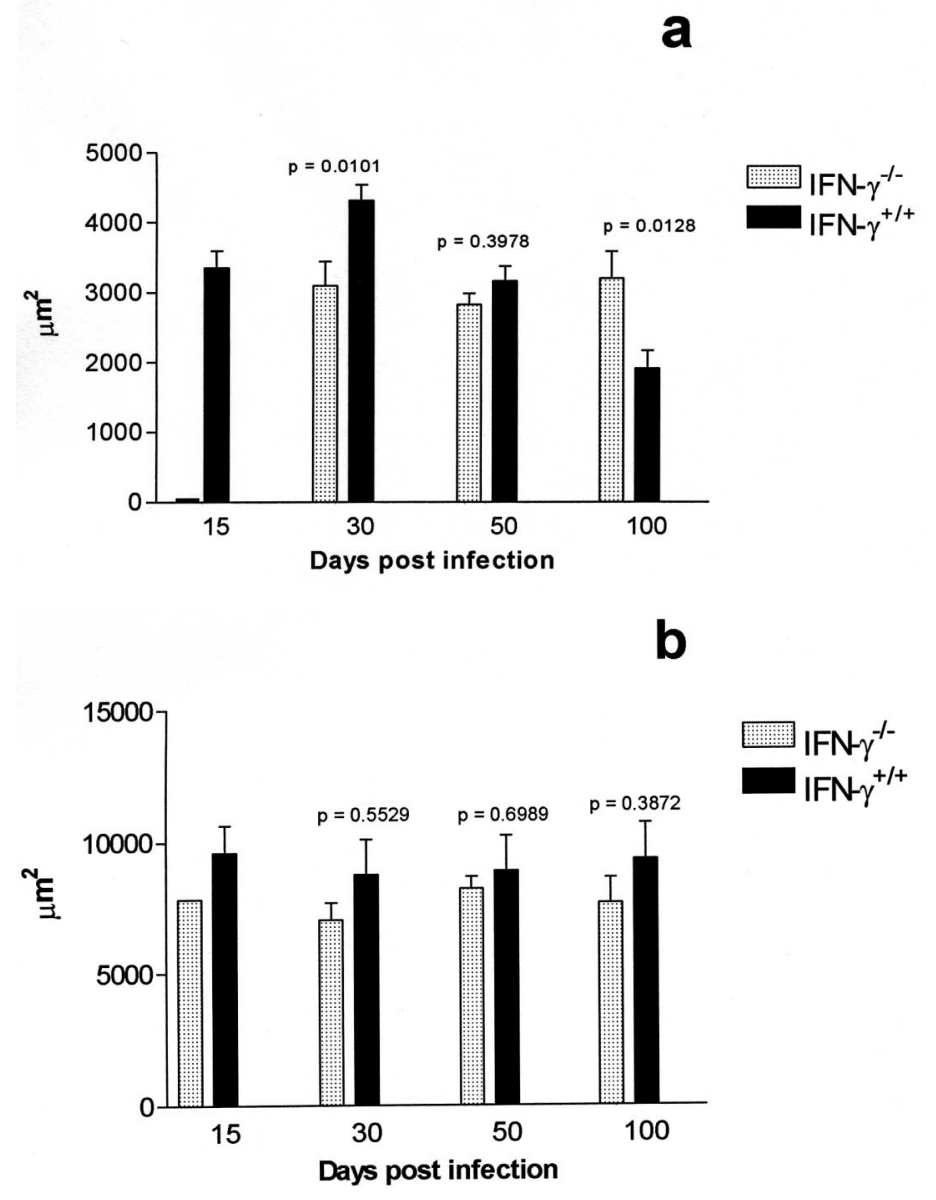

Fig. 2. Sectional of area of hepatic (a) and pulmonary (b) granulomas.

portal tracts and others were scattered throughout the hepatic parenchyma. Granulomas, in the pulmonary tissue, had a similar morphological appearance to that of the liver during the same 3050 days of infection.

The size of granulomas (Fig. 2) in liver and lungs were similar in all studied points

The volume density of the granulomas yielded similar values between 30 and 50 days (Fig. 3) in both tissues of IFN- $\gamma^{\prime-}$ mice. Granulomatous lesions persisted up to 100 days post infection in both tissues. These delayed lesions were frequently characterized by an accumulation of lymphocytes and absence of epithelioids cells.

IFN- $\gamma^{+/+}$mice - At 15 days after M. bovis inoculation, the liver of wild type mice contained numerous randomly distributed small granulomatous inflammatory areas that were poorly demarcated. These granulomas were composed by macrophages, occasionally lymphocytes. No multinucleated (Langerhans) cells were seen.
The number of granulomas in the liver was greater than the number of granulomas in lungs at this time point (Fig. 1a). Caseous necrosis was not observed in the tissues in any animals in any time of infection. Morphological analysis and morphometrical measurements of hepatic and pulmonary tissues lesions from wild type animals 50 days after infection demonstrate distinct aspects of the granulomas in the both organs.

At 50 days after M. bovis infection, the liver of IFN- $\gamma^{+/+}$mice presented fewer and smaller granulomatous lesions than at 15 and 30 days of infection (Figs. 1a and 2a), which resulted in a smaller volumetric density of granulomas (Fig. $3 a)$. These granulomas consisted of macrophages and epithelioid cells. Lymphocytes were also present in the periphery of these granulomas. In the lungs of the wild type mice, after 50 days of infection, well-delimited granulomas were observed, surrounded by lymphocytes.

At 100 days of infection, significant differences were observed by comparing the liver and lungs. In the liver, there was a diminishment of the granulomatous inflammation, while in the lungs the chronic inflammation persisted.

\section{DISCUSSION}

The present study demonstrated that IFN-g is required for defense against $M$. bovis infection in mice. Therefore in the absence of this cytokine, the animal had a gradual and uncontrolled infection. A small number of M. bovis ( $2 \times 105 \mathrm{CFU})$ was able to infect and induce granulomatous inflammation in liver and lungs. Other studies have been demonstrating, on the basis of host survival curve, that immunologically deficient mice die more rapidly than immunocompetent mice (Cooper et al., 1993; Flynn et al., 1995; Ladel et al., 1995).

Our results demonstrated a gradual increase of the bacillary load of mycobacteria in the liver and lungs of the IFN- $\gamma$ deficient mice; therefore, it clearly established that INF- $\gamma$ is a critical cytokine in the containment of the infection with M. bovis. IFN- $\gamma$ plays a significant role in the control of mycobacterial infections (Khalifeh \& Stabel, 2004), therefore mice lacking a functional gene for IFN- $\gamma$ are totally unable to contain and control a virulent $M$. tuberculosis infection (Cooper et al., 1993). 

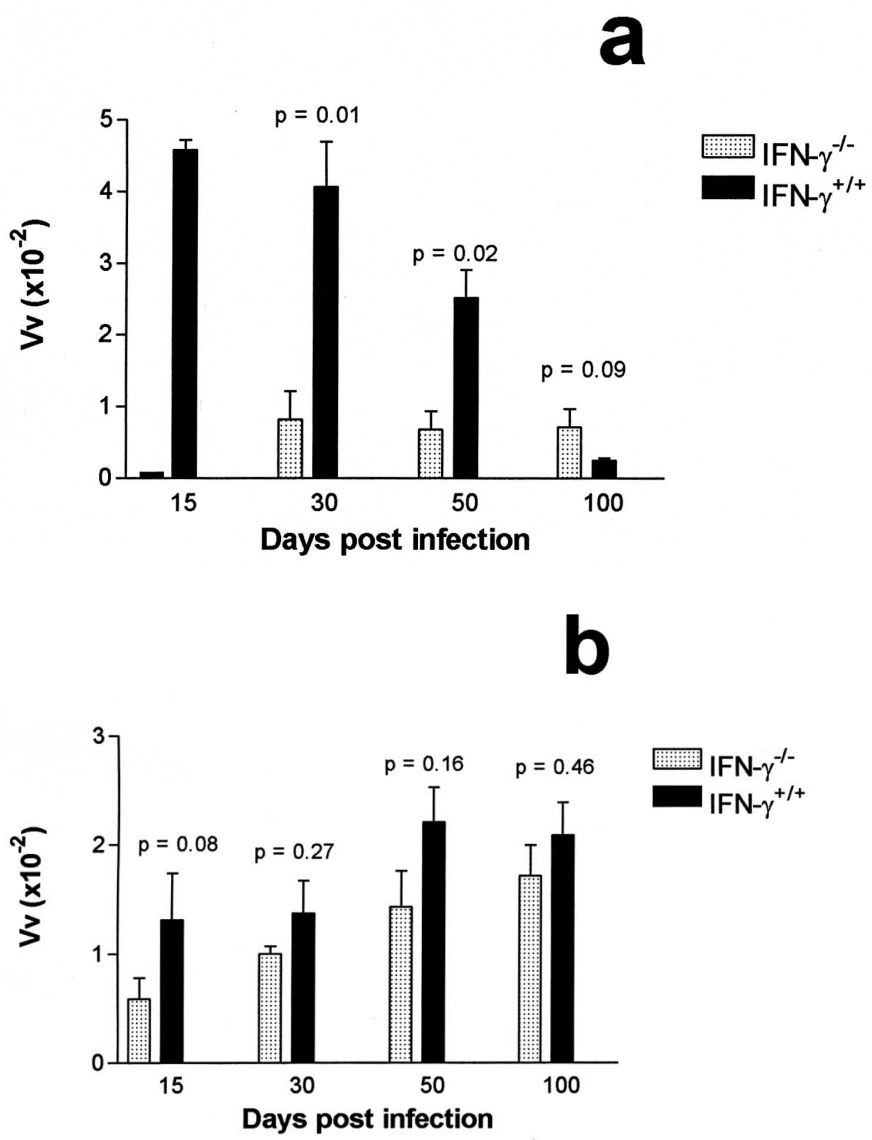

Fig. 3. Volumetric density of hepatic (a) and pulmonary (b) granulomas.

Many studies using gene-disrupted mice have shown that, in the absence of a functional IFN- $\gamma$-producing immune response, mice cannot control a sub lethal $M$. tuberculosis infection, regardless of whether some degree of granuloma formation occurs (Cooper et al., 1993; Flynn et al., 1993).
In our current experiments, by examining the kinetics of inflammation in liver and lungs, we demonstrate that IFN-g is also important to generate an adequate granulomatous response against $M$. bovis-infected mice and leads to significant control of the bacillus growth during the infection. The key defect in IFN- $\gamma^{-}$mice was inappropriate granuloma formation, with clearly altered cellular accumulations leading to eventual breakdown of the mononuclear granulomas. In the absence of IFN- $\gamma$, granulomas were formed by granulocytes, lymphocytes and few macrophages.

Ours data support the hypothesis that the influx of macrophages and subsequent granuloma formation is needed for long-term containment of mycobacterial infection and that the absence of this cytokine leads to the breakdown of the chronic disease state, increasing bacillary multiplication and severity of infection with $M$. bovis.

Our results emphasize the importance of the IFN- $\gamma$ in mycobactericidal pathways and suggest that a key role played by IFN- $\gamma$ in mediating protection in the mouse is the induction of actives macrophages, allowing formation of granulomas, an important microbicidal mechanism for protection against $M$. bovis infection.

DUARTE, A. T.; BARBOSA JR., A.A. \& ARRUDA, S. El Análisis morfométrico de granulomas inducidos por Mycobacterium bovis sugiere la influencia del IFN-Gamma en la generación y modulación de la respuesta inflamatoria granulomatosa en diferentes tejidos. Int. J. Morphol., 23(4):317-322, 2005.

RESUMEN: Existen evidencias, tanto en humanos como en modelos experimentales, que factores inmunológicos influencian. durante la infección causada por la Mycobacterium tuberculosis, tanto la infección como la progresión de la enfermedad. Este estudio se propone evaluar el papel de IFN- $\gamma$ en la respuesta inflamatoria granulomatosa contra $M$. bovis. Para ello, se inocularon ratones C57BL/6 knockout para IFN-g (IFN- $\gamma-/-$ ) y los correspondientes salvajes (IFN- $\gamma+/+$ ) con M. bovis. Evaluamos la capacidad de la $M$. bovis de sobrevivir y replicarse en el hígado y pulmones mediante la cuantificación de unidades formadoras de colonias (CPU). También analizamos los aspectos histopatológicos de la respuesta inflamatoria granulomatosa en el hígado y los pulmones durante la infección con M. bovis. Para cada punto de infección, se calcularon los parámetros del granuloma, tales como el tamaño (área de sección), el volumen del granuloma, la densidad de volumen y densidad numérica. La carga bacilar fue mayor en los dos órganos estudiados procedentes de los ratones IFN- $\gamma$-/-. Los granulomas de los ratones controles se detectaron a los 15 días, mientras que los de los ratones IFN- $\gamma$ no se detectaron hasta los 30 días post infección. Los granulomas hepáticos persistieron en los ratones IFN- $\gamma$-/-. Como conclusión es posible afirmar que el IFN- $\gamma$ influencia la multiplicación por $M$. bovis, así como también modula la inflamación granulomatosa.

PALABRAS CLAVE: Morfometría; Mycobacterium; Tuberculosis; IFN- $\gamma$; Granuloma. 


\section{REFERENCES}

Bloom, B. R. \& Murray, C.J. Tuberculosis: commentary on a reemergent killer. Science, 257(5073):1055-64, 1992.

Cooper, A. M. \& Flynn, J. L. The protective immune response to Mycobacterium tuberculosis. Curr. Opin. Immunol., 7(4):512-6, 1995.

Cooper, A. M.; Dalton, D. K.; Stewart, T. A.; Griffin, J.P.; Russel, D.G. \& Orme, I.M. Disseminated tuberculosis in interferon g gene-disrupted mice. J. Exp. Med., 178(6):22437, 1993.

Cree, I.A.; Srinivasan, T.; Krishnan, S.A.R.; Gardiner, C.A.; Mehta, J.; Fisher, C.A. \& Beck, J.S. Reproducibility of histology in leprosy lesions. Int. J. Lepr. Other. Mycobact. Dis., 56(2):296-301, 1988.

Dannenberg, A. M. \& Rook, G. S. W. Pathogenesis of pulmonary tuberculosis: interplay of tissue-damaging and macrophage-activating immune responses - dual mechanisms that control bacillary multiplication. In Bloom, BR. Tuberculosis: pathogenesis, protection, and control. ASM Press, Washington, 1994.

Flesch, I. E. \& Kaufmann, S. H. Activation of tuberculostatic macrophage functions by gamma interferon, interleukin-4, and tumor necrosis factor. Infect. Immun., 58(8):2675-7, 1990.

Flynn, J. L. \& Chan, J. Immunology of tuberculosis. Annu. Rev. Immunol., 19:93-129, 2001.

Flynn, J. L.; Chan, J.; Triebold, K.; Dalton, D. K.; Stewart, T. A. \& Bloom, B.R. An essential role for interferon $\mathrm{g}$ in resistance to Mycobacterium tuberculosis infection. J. Exp. Med., 178(6):2249-54, 1993.

Flynn, J. L.; Goldstein, M. M.; Chan, J.; Triebold, K. J.; Pfeffer, K.; Lowenstein, C. J.; Schreiber, R.; Mak, T.W. \& Bloom, B. R. Tumor necrosis factor-alpha is required in the protective immune response against Mycobacterium tuberculosis in mice. Immunity, 2(6):561-72, 1995.

Gammack, D.; Doering, C. R. \& Kirschner, D. E. Macrophage response to Mycobacterium tuberculosis infection. J. Math. Biol., 48(2):218-42, 2004.

Hogan, L. H.; Markofski, W.; Bock, A.; Barger, B.; Morrissey, J.D. \& Sandor, M. Mycobacterium bovis BCG-Induced granuloma formation depends on gamma interferon and CD40 ligant but does not require CD28. Infect. Immun., 69(4):2596-603, 2001.
Janeway, C. A.; Travers, P.; Walport, M. \& Shlomchik, M. Immunobiology. Garland, NewYork, 1994.

Khalifeh, M. S. \& Stabel, J. R. Effects of gamma interferon, interleukin-10, and transforming growth factor beta on the survival of Mycobacterium avium subsp. paratuberculosis in monocyte-derived macrophages from naturally infected cattle. Infect. Immun., 72(4):1974-82, 2004.

Ladel, C. H.; Daugelat, S. \& Kaufmann, S. H. E. Immune response to Mycobacterium bovis bacilli Calmette Guérin infection in major histocompatibility complex class I- and II-deficient knock-out mice: contribution of CD4 and CD8 T cells to acquired resistance. Eur. J. Immunol., 25(2):37784, 1995.

Orme, I.M. \& Cooper, A.M. Cytokine/chemokine cascades in immunity to tuberculosis. Immunol. Today., 20(7):307-12, 1999.

Robbins. Pathology Basis of Diseases. 6th ed., W. B. Saunders Company, Philadelphia, Pensylvania, 83 pp., 1999.

Wakeham, J.; Wang, J.; Magram, J.; Croitoru, K.; Harkness, R.; Dunn, P.; Zganiacz, A. \& Xing, Z. Lack of both types 1 and 2 cytokines, tissue inflammatory responses, and immune protection during pulmonary infection by Mycobacterium bovis Bacille Calmette-Guérin in IL-12-deficient mice. J. Immunol., 160(12):6101-11, 1998.

Weibel, E.R. Stereological principles for morphometry in electron microscopie cytology. Int Rev Cytol., 26:235-302, 1969.

Correspondence to:

Dr. Sérgio Arruda

Centro de Pesquisa Gonçalo Moniz - FIOCRUZ

Laboratorio de Histopatolologia

R. Waldemar Falcão, 121 - Candeal

CEP: 40296-710

Salvador - BA - BRAZIL

FAX: (0xx71) 3356-2155

Email: arruda@cpqgm.fiocruz.6r

Received : 23-06-2005

Accepted: 28-09-2005 